【論文】

\title{
ハンディタイプオープンパス型計測器による 大気環境中メタン計測手法の廃棄物最終処分場への適用
}

\author{
谷川昇 ${ }^{*}$. 古市徹 ${ }^{*}$ - 石 井一 英 ${ }^{*}$ \\ 松尾晃 治* - 井関孝 弥 ${ }^{* *}$
}

【要 旨】市販のハンディタイプオープンパス型都市ガス漏れ検知器（オープンパス型メタン計測器） と反射板を用いた簡便な大気環境中の平均メタン濃度の計測手法を提案し，その計測手法の測定値の信 頼性と実際の最終処分場への適用性を検討した。

オープンパス型メタン計測器を用いたメタン濃度の測定值は, 水素炎イオン化方式炭化水素自動計測 器 (FID 自動計測器) のメ夕ン濃度の測定值と良い相関関係が認められたこと，オープンパス型メ夕 ン計測器と反射板間の距離にほとんど影響されないこと, 再現性む良好であったことから, 提案した計 測手法によって, 大気環境中のメタン濃度を FID 自動計測器と同程度の精度で計測できることがわ かった。さらに, 提案した計測手法は, 実際の最終処分場内において, 平均メ夕ン濃度とその变化を簡 便かつ正確に把握でき, 埋立ガスによる作業環境への影響や埋立廃棄物の安定化の進行状況の把握等に 活用可能であることを示した。

キーワード：メタン，オープンパス型自動計測器, 最終処分場, モニタリング, 埋立ガス

\section{1. 緒言}

廃棄物最終処分場（以下最終処分場と記す）において は，埋立ガスは設置されたガス抜き管からだけではなく， 地表面全体からあ発生していると推定される。また, 種々の廃衰物が不均一に存在する埋立層内の温度, 水分, 酸素分圧, 微生物種等の物理化学・生物化学的条件等は 多様であり, 発生する埋立ガスの組成や量は, 場所に よって異なる ${ }^{1)}$ と考えられる。したがって，最終処分場 内の作業環境や周辺環境に及ぼす埋立ガスの影響の検討, 埋立ガスによる埋立廃棄物の安定化の進行状況の推定之 最終処分場の廃止の判定 ${ }^{2)}$, 埋立ガスの主成分であるメ タンと二酸化炭素の地球温暖化への寄与の推算等を行う ために, 最終処分場全体からの埋立ガスの発生状况を把

原稿受付 2006.2. 7 原稿受理 2006.6.22

* 北海道大学大学院工学研究科

** 東京ガス椒技術開発部

連絡先： $\mathbf{\top} 060-8628$ 北海道札幌市北区北 13 条西 8 丁目 北海道大学大学院工学研究科 谷川 昇
握するには，ガス抜き管や地表面から数多くの埋立ガス

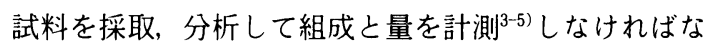
らない。しかし，その実施にあたっては, 多大な労力と 経費や結果を得るまでの長い時間が必要となるので, 埋 立ガスの発生状況を簡便かつ正確にモニタリングする標 準手法の開発が強く求められ，その取組が報告6)されて いる。

筆者らは, 最終処分場では埋立ガス中のメタンが大気 環境中メタン濃度を上昇させる主たる発生源と考えられ ること, 通常の都市大気環境中のメタン濃度は $2 \mathrm{ppm}$ 程度でほぼ安定している77ので埋立ガスの影響によるメ タン濃度上昇を容易に計測可能であること，大気環境測

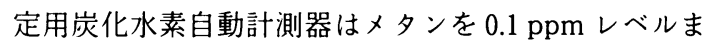
で計測できること等から，最終処分場全体からの埋立ガ ス発生状況のモニタリング方法として, 大気環境中のメ タン濃度を指標とする手法の検討を進めている。そして, 埋立ガスが希釈拡散してある程度均質化された最終処分 場周辺の大気環境中メタン濃度の長期モニタリングに よって, 埋立ガスの発生状況を把握できることを示して いる8. 9)。 
しかし，埋立ガスが作業環境と周辺環境に及ぼす影響 や埋立廃棄物の安定化の進行状況等をより詳細に検討す るためには, 埋立ガスの希釈拡散が不十分で濃度分布が あると推測される最終処分場内での大気環境中メタン平 均濃度を簡便に計測する必要がある。その計測方法とし ては, 欧米で開発された $100 \mathrm{~m}$ を超える長い距離の一 定空間のガス平均濃度を計測するオープンパス型自動計 測器 ${ }^{10)}$ の活用が考えられ, 日本においても最終処分場で

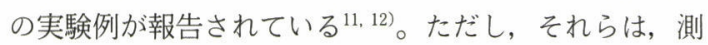
定空間を固定してガス濃度を計測する重さが数十 kg の 光学的調整が必要な定置型計測器であるために, 最終処 分場の限られた場所でのメタン平均濃度の連続計測を想 定したものである。すなわち, 最終処分場全体のメタン 平均濃度を把握するには, 容易に移動できるオープンパ ス型自動計測器を用いて, 任意の空間の平均濃度を機動 的に計測できる手法を開発しなければならない。

そこで, 本研究では, 市販の軽量なハンディタイプ オープンパス型都市ガス漏れ検知器を用いた大気環境中 のメタン平均濃度の計測手法を提案し, その計測手法の 測定値の信頼性と最終処分場への適用性を検討した。

\section{2. 実験}

\section{1 装置と計測原理}

実験に使用したアンリツ(株) 製ハンディタイプオープ ンパス型都市ガス漏れ検知器（商品名はレーザーメタン 検知器, 以下オープンパス型メタン計測器と記す) の仕 様を Table 1 に示す。オープンパス型メタン計測器は, 電池を内蔵した軽量な可搬タイプの機器であり, 天然ガ ス等のメタンを含むガスの漏洩・滞留を $10 \mathrm{~m}$ 程度離れ た場所からでも検知するために開発された ${ }^{13-15)} 。$ 測定原 理は, 計測器の発光部の光源から壁等の任意の標的に照 射されたレーザー光の後方散乱光の一部を受光部の検知 器で受け, 計測器と標的の往復レーザー光の吸収率から
レーザー光路上のメタン濃度の積分值であるメタンコ ラム密度 $(\mathrm{ppm} ・ \mathrm{~m})$ を約 1 秒間隔で計測するもので あり, 設定值以上の值が計測されると警報を発する。 レーザー光の波長は, メタンの特異的吸収波長である $1,653.7 \mathrm{~nm}$ を利用している。この波長は, 大気環境中 の共存ガスの影響を受けない。また, オープンパス型メ タン計測器の校正は, あらかじめ作成された検量線を基 にして, 使用時に自動的に行われるシステムになってい る。

本研究では, このような特徵を有するオープンパス型 メタン計測器と反射板を組み合わせて, Fig. 1 に示す ような方法で, 大気環境中メタン濃度を計測する手法を 検討した。反射板としては, 従来の定置型オープンパス 型自動計測器で使用されている微妙な調整が必要な光学 系の鏡ではなく, 調整が一切不要なスリーエム社製の三 面体キューブ素子を採用したフィルム状の反射板 ${ }^{16)}$ (約 $50 \mathrm{~cm} \times 50 \mathrm{~cm} \times 0.3 \mathrm{~cm}$ ）を利用した。この反射板は, 反射輝度が高く広角性に優れており, 道路標識等にも広 く使われている。

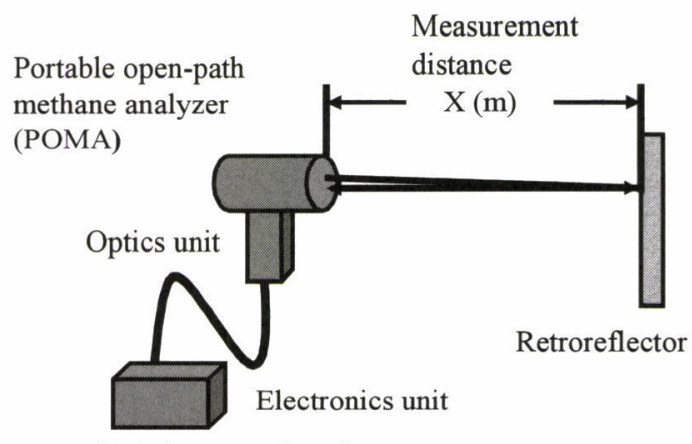

Path-integrated methane concentration $\mathrm{D}(\mathrm{ppm} \cdot \mathrm{m}) \quad \mathrm{CH}_{4}(\mathrm{ppm})=\mathrm{D} / \mathrm{X}$

Fig. 1 Schematic of the monitoring method for concentration of $\mathrm{CH}_{4}$ using a portable open-path methane analyzer and a retroreflector

Table 1 Specifications and performance of the portable open-path type methane analyzer tested

\begin{tabular}{ll}
\hline Detection principle & $\begin{array}{l}\text { Wavelength-modulation spectroscopy } \\
\text { for infrared absorption }\end{array}$ \\
\hline Light source & InGaAsP distributed-feedback laser \\
\hline Wavelenght $(\mathrm{nm})$ & $1,653.7$ \\
\hline Response time $(\mathrm{s})$ & 0.1 \\
\hline Lower detection limit $(\mathrm{ppm} \cdot \mathrm{m})$ & 50 \\
\hline Upper detection limit $(\mathrm{ppm} \cdot \mathrm{m})$ & \multicolumn{2}{c}{6,000} \\
\hline Weight $(\mathrm{kg})$ & \multicolumn{2}{c}{4.4 in total } \\
\hline Dimensions $(\mathrm{mm})$ & $\begin{array}{l}\text { Electronics unit : W 195 } \times \text { D 260 } \times \text { H } 88 \\
\text { Optics unit }\end{array}$ \\
\hline Nickel-metal hydrate battery $(\mathrm{V})$ & \multicolumn{2}{l}{$114 \times \mathrm{D} \mathrm{244} \times \mathrm{H} 206$} \\
\hline
\end{tabular}


本手法では, オープンパス型メタン計測器からレー ザ一光を反射板に照射して，オープンパス型メタン計測 器と反射板との間のメタンコラム密度を計測し，（1） 式によりレーザー光路上のメタン平均濃度を算出する。 メタンコラム密度の表示值が変動する場合には, 約 1 秒 間隔で得られる 10 程度の表示値の平均を測定値とする。

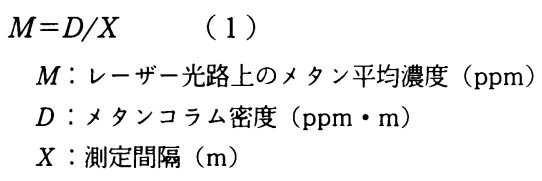

$M:$ レーザー光路上のメタン平均濃度 $(\mathrm{ppm})$

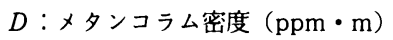

$X:$ 測定間隔 $(\mathrm{m})$

オープンパス型メタン計測器は固定電源不要で軽量か つ操作が簡単であること, 反射板は軽量で光学的調整が 不要なことから，これらを最終処分場内の任意の場所に 随時移動して，メタンコラム密度およびオープンパス型 メタン計測器と反射板との間隔（以下測定間隔とする） を計測すれば, 最終処分場全体の大気環境中メタン平均 濃度をリアルタイムで簡便かつ短時間に把握できる。

\section{2 実験方法}

2.2.1 オープンパス型メタン計測器を用いた大気環境 中メタン計測手法の測定値の信頼性

オープンパス型メタン計測器と反射板を用いた大気環 境中メタン計測手法の測定值の精度を検討するために,

Table 2 Specifications of hydrocarbon analyzer tested

\begin{tabular}{lc}
\hline Detection principle & $\begin{array}{l}\text { Flame ionization } \\
\text { detector method }\end{array}$ \\
\hline Lower detection limit $(\mathrm{ppm})$ & 0.1 \\
\hline Upper detection limit $(\mathrm{ppm})$ & 50 \\
\hline Sample flow $(\mathrm{mL} / \mathrm{min})$ & 900 \\
\hline
\end{tabular}

約 $20^{\circ} \mathrm{C}$ に保ったほぼ密閉状態の実験室 $(15 \mathrm{~m} \times 8 \mathrm{~m} \times$ $3 \mathrm{~m})$ 内のメタン濃度を, オープンパス型メタン計測器 と Table 2 に示す大気環境中のメタン濃度測定に使用 されている (株) 堀場製作所製水素炎イオン化検出法炭化 水素自動計測器 APHA-360 (以下 FID 自動計測器と記 す）によって測定し, 両方の測定値を比較した。まず,

メタン標準ガスを実験室内に適量放出し, 送風器で室内 をかくはんしてメタンと空気との混合を図った。そして, Fig. 2 に示すように，ガス採取管を移動して調べた A, $\mathrm{B}, \mathrm{C}, \mathrm{D}, \mathrm{E}$ の地点での FID 自動計測器の測定値が等し いことを確認した上で, オープンパス型メタン計測器と FID 自動計測器によって, それぞれ測定間隔 $10 \mathrm{~m}$ の空 間と A 地点のメタン濃度を測定した。メタン濃度は, 実際の廃棄物最終処分場での濃度を想定して ${ }^{8)}$, 約 2 $40 \mathrm{ppm}$ の範囲で変化させた。

また, 特定のメタン発生源がなく, FID 自動計测器 によってメタン濃度が一定であることを確認した屋外と 建屋内において，測定間隔をそれぞれ $4 \sim 32 \mathrm{~m}, 10$ $50 \mathrm{~m}$ に変化させてオープンパス型メタン計測器による メタン濃度の測定を行い, 測定値と測定間隔との関係を 検討した。さらに，測定間隔を $20 \mathrm{~m}$ と $50 \mathrm{~m}$ に保って オープンパス型メタン計測器によるメタン濃度の測定を 繰り返して行い, 測定值の再現性を検討した。

2.2.3 オープンパス型メタン計測器を用いた大気環境 中メタン計測手法の最終処分場への適用性

(1) 対象最終処分場

Table 3 に示す最終処分場において，オープンパス型 メタン計測器と反射板を用いた大気環境中メタン濃度の 計測手法の適用性を明らかにする実験を行った。

$\mathrm{A}$ 最終処分場は, 屋根と外壁によって外部と仕切ら れたクローズドシステム型処分場であり，不燃ごみ破砕

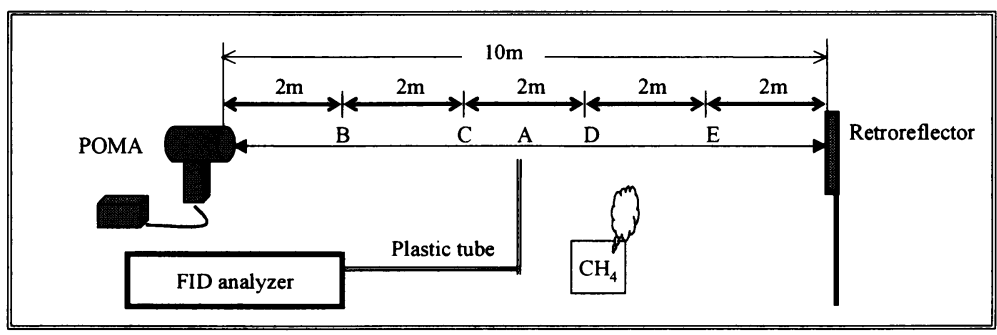

Fig. 2 Schematic of the comparative experiment

Table 3 Outline of landfill sites tested

\begin{tabular}{ccccc}
\hline $\begin{array}{c}\text { Landfill } \\
\text { site }\end{array}$ & Type & $\begin{array}{c}\text { Duration of } \\
\text { reclamation }\end{array}$ & $\begin{array}{c}\text { Reclamation } \\
\text { area }\left(\mathrm{m}^{2}\right)\end{array}$ & Landfilled solid waste \\
\hline A & $\begin{array}{c}\text { Controllable } \\
\text { closed system }\end{array}$ & $2002-$ & 1,000 & $\begin{array}{c}\text { Residue of pulverized incombustible waste, plastics } \\
\text { and bulky waste (particle size: under }\end{array}$ \\
\hline B & Open & $1979-$ & 101,500 & All domestic waste \\
\hline
\end{tabular}


$7 \mathrm{~m}$ above the landfill surface

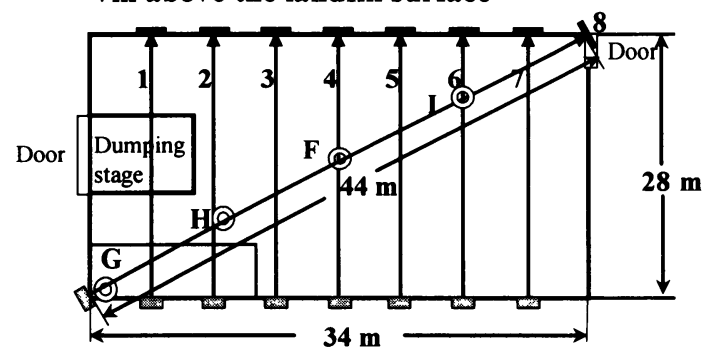

$1.5 \mathrm{~m}$ above the landfill surface

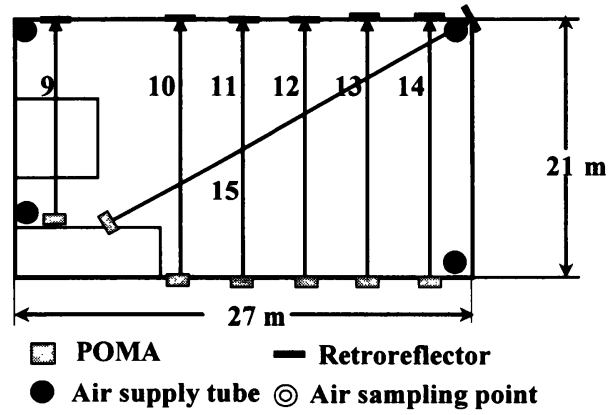

Fig. 3 Monitoring for concentration of $\mathrm{CH}_{4}$ at Landfill site A

残椬等を覆土は行わずに埋め立てている。外壁にある限 られたガラリを通して少量の空気が出入するが，場内は ほぼ密閉された状態が保たれており, 埋立廃棄物から発 生した埋立ガスは, 通常は場内に滞留すると考えられる。 ただし，廃棄物の般入や敷きならしなどの埋立作業等に 伴い, 出入口扉を開けて給気装置 $\left(300 \mathrm{~m}^{3} / \mathrm{h}\right) 4$ 台と 排気装置 $\left(15,000 \mathrm{~m}^{3} / \mathrm{h}\right) 2$ 台を作動させる場合には, 場内の空気は流入する外気と混合される。

$\mathrm{B}$ 最終処分場は, 剭芥類を含む粗破砕した一般廃衰物 を, サンドイッチ工法により直接埋め立てているオープ ン型処分場である。全体を 4 期にわけて埋立作業を行っ ており, 第 1 期エリアと第 2 期エリアは既に埋立が終了 し, 第 3 期エリアと第 4 期エリアでは, 埋立が行われて いる。埋立が終了した場所には, 約 $1.5 \mathrm{~m}$ の厚さで最終 覆土が施工されている。

(2) 方 法

A 最終処分場では, Fig. 3 に示すように, 廃裹物埋 立面より高さ $7 \mathrm{~m}$ の処分場の対角線方向 8 の空間のメ タン濃度をオープンパス型メタン計測器によって間欠的 に測定するとともに, オープンパス型メタン計測器の光 路直下にロープを張って配管したポリエチレン製チュー

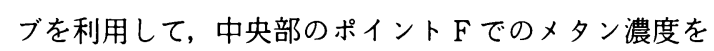
FID 自動計測器によって連続測定した。また, 光路直 下のポイント G, H, I の 3 箇所の大気を $5 \mathrm{~L}$ のポリエス

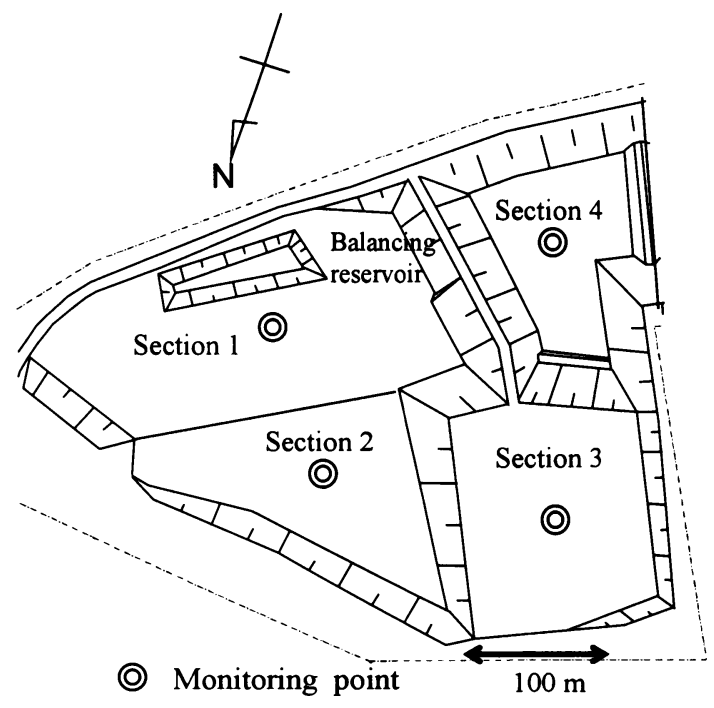

Fig. 4 Monitoring point of $\mathrm{CH}_{4}$ at Landfill site B

テル製袋に一定間隔で同時に吸引採取し, FID 自動計 測器によって採取空気中のメタン濃度を測定した。さら に, 埋立作業終了後に出入口屝を閉め, 排気装置を停止 して給気装置のみを稼㗢させて埋立面に外気を導入して いる条件で, オープンパス型メタン計測器と反射板を移 動しながら, Fig. 3 に示すように, 廃裹物埋立面より 高さ $7 \mathrm{~m}$ と $1.5 \mathrm{~m}$ のそれぞれ $1 \sim 8,9 \sim 15$ の空間の メタン濃度を計測し，メタン濃度分布の状況を検討した。 B 最終処分場では, Fig. 4 に示すように, 第 1 期, 第 2 期, 第 3 期, 第 4 期の各エリアのほぼ中央部において, 測定間隔が $20 \mathrm{~m}$, 高さが $1.2 \mathrm{~m}$ の大気環境中のメタン 濃度を, 2 分間隔で約 10 回測定した。なお, 測定にあ たっては, 約 $30 \sim 40 \mathrm{~m}$ 間隔で設置されているガス抜 き管から排出されるメタンの直接的な影響をできるだけ 受けない場所に, オープンパス型自動計測器と反射板を 配置した。

\section{3. 結果および考察}

\section{1 オープンパス型メタン計測器を用いた大気環境中 メタン計測手法の測定值の信頼性}

実験室内において, メタン濃度を約 $2 \sim 40 \mathrm{ppm}$ の範 囲で変化させ, 測定間隔を $10 \mathrm{~m}$ に保ったときのオープ ンパス型メタン計測器の測定値と FID 自動計測器の測 定値との関係を Fig. 5 に示す。Fig. 5 の一次回㷌直線 は, ほぼ原点を通るとともに，傾きは $0.97, \mathrm{R}^{2}$ は 0.999 と 1 に極めて近い值となり,オープンパス型メタン計測 器の測定値と FID 自動計測器の測定値には極めて良好 


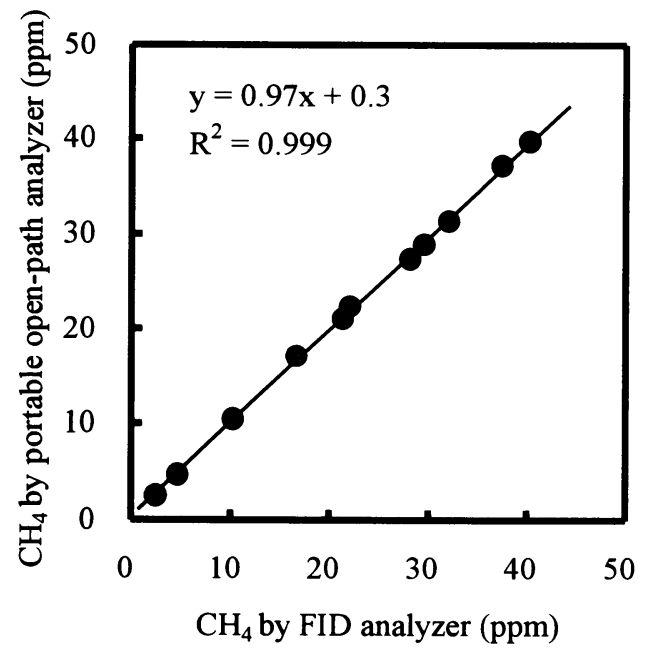

Fig. 5 Correlations between the values measured by the portable open-path methane analyzer and by the FID type hydrocarbon analyzer

Table 4 Results of distance dependence on measured value

\begin{tabular}{lccc}
\hline Condition & $\begin{array}{c}\text { Range of } \\
\text { distance } \\
(\mathrm{m})\end{array}$ & $\begin{array}{c}\text { Average } \\
\text { of } \mathrm{CH}_{4} \\
(\mathrm{ppm})\end{array}$ & $\begin{array}{c}\text { Coefficient } \\
\text { of variation } \\
(\%)\end{array}$ \\
\hline Outdoor air & $4-32$ & 2.1 & 2.3 \\
\hline Indoor air & $10-50$ & 2.2 & 5.8 \\
\hline
\end{tabular}

Table 5 Results of repeatability test

\begin{tabular}{lcccc}
\hline Condition & $\begin{array}{c}\text { Average } \\
\text { of } \mathrm{CH}_{4} \\
(\mathrm{ppm})\end{array}$ & $\begin{array}{c}\text { Coefficient } \\
\text { of variation } \\
(\%)\end{array}$ & $\begin{array}{c}\text { Distance } \\
\text { (m) }\end{array}$ & $\begin{array}{c}\text { Repeat } \\
\text { number }\end{array}$ \\
\hline Outdoor air & 2.1 & 1.8 & 20 & 10 \\
\hline Indoor air & 2.2 & 5.6 & 50 & 7 \\
\hline
\end{tabular}

な相関が得られた。

特定のメタン発生源がない屋外亡建屋内において, 測 定間隔を屋外では $4,10,15,20,25,30,32 \mathrm{~m}$ に, 建屋 内では $10,15,20,25,30,35,50 \mathrm{~m}$ に保ったときのオー プンパス型メタン計測器の測定值の変動をTable 4 に 示す。屋外と建屋内の測定值の変動係数は, それぞれ 2.3，5.8\% と比較的小さな值であり，オープンパス型メ タン計測器の測定值の距離依存性はほとんどないと考え られた。また，屋外之建屋内において，オープンパス型 メタン計測器を用いてメタン濃度を繰り返し測定した結 果をTable 5 に示す。繰り返し測定の変動係数む十分 に小さい值であり, オープンパス型メタン計測器を用い たメタン濃度測定値の再現性は良好であるといえる。
これらの結果から、オープンパス型メタン計測器と反 射板を用いる手法によって，大気環境中メタン濃度を FID 自動計測器と同程度の精度で簡便に計測できるこ とがわかった。

\section{2 オープンパス型メタン計測器を用いた大気環境中 メタン計測手法の最終処分場への適用性}

\subsubsection{A 最終処分場}

FID 自動計測器によって連続測定した場内中央部の ポイントFのメタン濃度は, 埋立物である不燃ごみ破 砕残椬中の有機物が分解しているために, 屋外の大気環 境中のメタン濃度 $2.1 \mathrm{ppm}$ 上り高く, 約 $2.5 \sim 4 \mathrm{ppm}$ の範囲で変化していた。

Fig. 3 に示した FID 自動計測器によるポイント F の メタン濃度とオープンパス型メタン計測器による処分場 対角線方向 8 のメタン濃度の測定例を Fig. 6 に示す。 18 分までの時間帯は, 出入口扉を閉じて給排気装置は 停止した埋立作業が行われていない状態であり，ポイン トFのメタン濃度は, 約 $3 \sim 4 \mathrm{ppm}$ であった。18 分に 埋立作業のために出入口扉を開けて給排気装置を作動さ せると, 外気が屋内へ流入して場内のメ夕ン濃度が徐々 に低下していく状況が, FID 自動計測器によって連続 モニタリングされた。オープンパス型メタン計測器の測 定值は, 埋立作業開始前後を通して FID 自動計測器の 測定値と良く一致しており，場内のメ夕ン濃度の変化を 良く捉えていた。

上記の条件において，ポイント F, G, H, I での測定 值, これらのポイントの測定値の平均値およびオープン パス型メタン計測器の測定値の変化を Fig. 7 に示す。

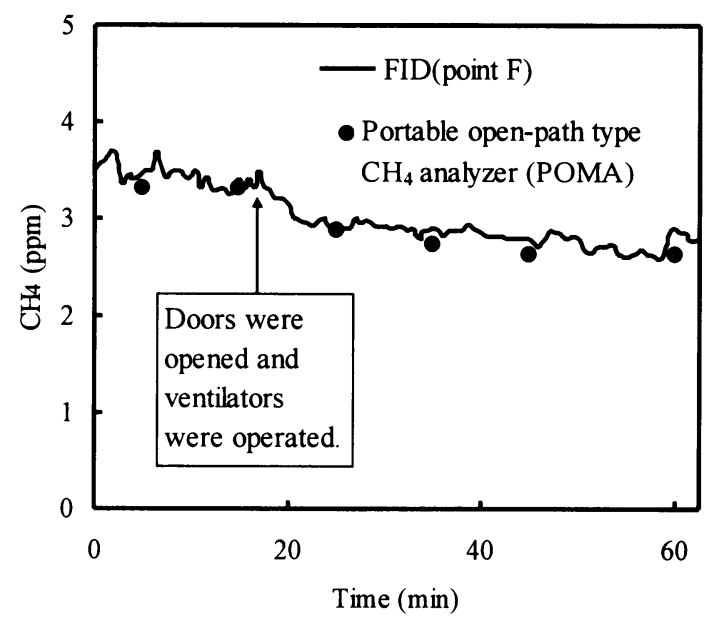

Fig. 6 An example of the change in concentration of $\mathrm{CH}_{4}$ at Landfill site $\mathrm{A}$ 
Table 6 Examples of concentration of $\mathrm{CH}_{4}$ at $7 \mathrm{~m}$ and $1.5 \mathrm{~m}$ above the surface of Landfill site $\mathrm{A}$

\begin{tabular}{cccc}
\hline Condition & $\begin{array}{c}\text { Average of } \mathrm{CH}_{4} \\
(\mathrm{ppm})\end{array}$ & $\begin{array}{c}\text { Coefficient of variation } \\
(\%)\end{array}$ & Number of sample \\
\hline $7 \mathrm{~m}$ above the landfill surface & 3.0 & 2.3 & 8 \\
\hline $1.5 \mathrm{~m}$ above the landfill surface & 2.6 & 5.8 & 7 \\
\hline
\end{tabular}

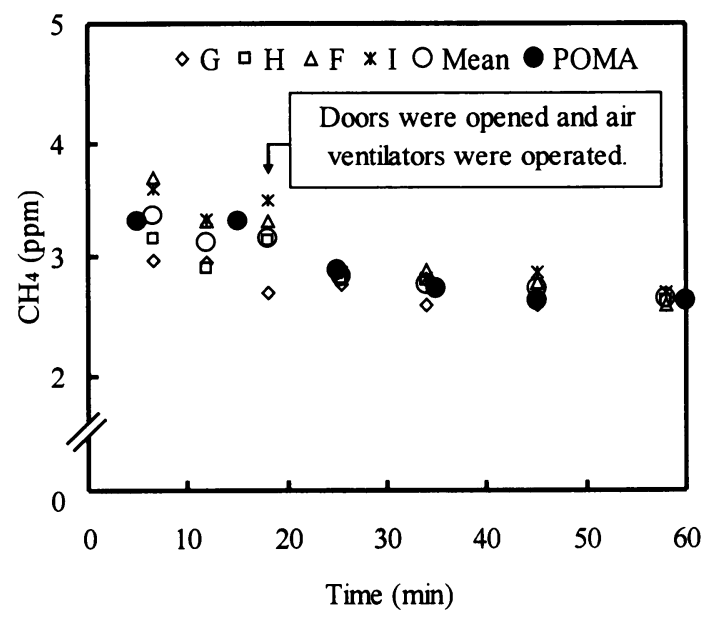

Fig. 7 Another example of the change in concentration of $\mathrm{CH}_{4}$ at Landfill site A

埋立作業開始前までは，ポイント F, G， H，Iのメタン 濃度には最大で $0.8 \mathrm{ppm}$ の差がみられ, 最終処分場内 の空間のメタン濃度には, 場所によって僅かな違いがあ ることがわかった。しかし，オープンパス型メタン計測 器の測定值は, ポイント F, G, H, I の測定値の平均值 とほぼ一致しており, 最終処分場内のメタン濃度の代表 値になっていると考えられた。

そして，埋立作業か開始されると，ポイント F, G, H, I のメタン濃度は, 時間経過とともに同程度になる結果 が得られた。これは, 出入口屝の開放之空気給排気装置 の稼働によって, メタン濃度 $2.1 \mathrm{ppm}$ の外気が最終処 分場内に流入して場内の大気の混合が促進され, 空間の メタン濃度の差が解消されたためと考えられる。この時 間帯においても, オープンパス型メタン計測器の測定值 は, ポイント F, G, H, I の測定值の平均値と良く一致 しており, 最終処分場内のメタン濃度の代表値となって いた。

さらに, 出入口霏を閉めて排気装置を停止し, 給気装 置のみを稼働させた条件で, 廃棄物埋立面より高さ 1.5 $\mathrm{m}$ と $7 \mathrm{~m}$ の空間のメタン濃度を, オープンパス型メタ ン計測器と反射板を移動しながら約 $4 \mathrm{~m}$ 間隔で計測し たところ，それぞれの平面でのメ夕ン濃度は，ほぼ一定 であり, 変動係数は Table 6 に示すように小さい値で あった。ただし, 高さ $1.5 \mathrm{~m}$ のメタン濃度は, 高さ $7 \mathrm{~m}$
のメタン濃度より $0.4 \mathrm{ppm}$ 程度低かった。その後に, 給気装置も停止させて約 20 時間経過した条件で, 高さ 約 $1.5 \mathrm{~m}$ と約 $7 \mathrm{~m}$ の平面上で測定したメタン濃度は, ほぼ等しかったことから,この $0.4 \mathrm{ppm} の$ 差は, 給気 装置によって 4 箇所の給気口から外気が場内の埋立面に 近くに導入されていたためと推定された。

このように, オープンパス型メタン計測器と反射板を 組み合わせた手法によって, 最終処分場での埋立ガスに よる作業環境への影響や埋立廃棄物の安定化状况等の把 握に必要な大気環境中の平均メタン濃度を正確かつ簡便 に把握できることがわかった。なお，本手法によるメ夕 ン濃度の測定は, 反射板を三脚等に固定すれば, 一人で あ実施可能であるが，二人一組でオープンパス型メタン 計測器と反射板の移動と計測を担当すると効率的な測定 ができる。Table 6 の結果を得るために約 $4 \mathrm{~m}$ 間隔で のメタン濃度測定を二人一組で実施したが，測定間隔を あらかじめ計測しておけば, 移動時間も含めて 1 箇所あ たりの測定所要時間は 1 分程度であった。

\subsubsection{B 最終処分場}

オープン型処分場である B 最終処分場では, 大気環 境中のメタン濃度は, 測定地点近傍から発生するメタン 量と風等で移流する大気の影響を受けると考えられるの で, 各埋立エリアにおけるメタン濃度は変動していた。 メタン濃度の変動範囲と平均值を Table 7 に示すが, 測定時の主風向は南で風速は $3 \mathrm{~m}$ 程度であった。

各埋立エリアのメタン濃度の平均は $4.1 \sim 10 \mathrm{ppm}$ で あり, ほぼ密閉状態の A 最終処分場のメタン濃度より 高い值であった。その理由は, 剭芥類を含む一般廃裹物 を埋め立てている B 最終処分場のメタン発生量が, 不 燃ごみ破磼残渣等を埋め立てている $\mathrm{A}$ 最終処分場より 多いためと考えられる。

Table 7 Examples of concentration of $\mathrm{CH}_{4}$ in ambient air at Landfill site B

\begin{tabular}{cccc}
\hline \multirow{2}{*}{ Site } & \multirow{2}{*}{$\begin{array}{c}\text { Duration of } \\
\text { reclamation }\end{array}$} & \multicolumn{2}{c}{$\mathrm{CH}_{4}(\mathrm{ppm})$} \\
\cline { 3 - 4 } & Range & Average \\
\hline Section 1 & $1979-1983$ & $3.3-6.0$ & 4.1 \\
\hline Section 2 & $1984-1992$ & $1.8-5.2$ & 4.1 \\
\hline Section 3 & $1993-$ & $1.8-9.6$ & 6.8 \\
\hline Section 4 & $1999-$ & $2.9-30.0$ & 10.0 \\
\hline
\end{tabular}


埋立が現在も行われている第 3 期と第 4 期のエリアの 平均メ夕ン濃度は, 埋立が終了している第 1 期と第 2 期 のエリアの測定値より高い値であり，第 4 期のエリアで は, 最大 $30 \mathrm{ppm}$ のメタン濃度が計測された。最終処分 場の供用開始から現在までの埋立廃棄物の組成がほとん ど変らないと仮定すると, このメタン濃度の違いは, 埋 立廃棄物中の有機物の微生物分解が活発に行われている 第 3 期と第 4 期のエリアからのメ夕ン発生量が，埋立が 終了してから相当の期間が経過して安定化が進んだ第 1 期と第 2 期のエリアより多いために生じたと考えられる。 また, メタン濃度が高い第 3 期と第 4 期のエリアが風上 となる西よりの風向の場合には，第 1 期と第 2 期のエリ アのメタン濃度が上昇する挙動が計測できた。

これまで3.2.1と3.2.2において述べた結果より，実際 の最終処分場において，オープンパス型メタン計測器と 反射板を用いた計測手法によって，大気環境中のメタン 平均濃度が簡便かつ機動的にモニタリングでき，この手 法が中小規模の最終処分場における埋立ガスによる作業 環境への影響や埋立廃棄物の安定化の進行状況の把握等 に活用可能であることを明らかにできた。

\section{4. 結論}

本研究では, オープンパス型メタン計測器と反射板を 用いた簡便な大気環境中の平均メタン濃度の計測手法を 提案し，その測定值と水素炎イオン化方式炭化水素自動 計測器（FID 自動計測器）のメタン濃度の測定值との 比較等を行うとともに, 計測手法の実際の廃棄物最終処 分場への適用性を検討したところ，次の結果が得られた。

(1) オープンパス型メタン計測器を用いたメタン濃度 の測定値は, FID 自動計測器の測定値と良い相 関関係が認められたこと，距離依存性がほとんど 無く再現性む良好であったことから，提案した計 測手法によって，大気環境中メタン濃度を簡便か つ FID 自動計測器と同程度の精度で計測できる。

(2) 提案した計測手法によって,メタンの濃度分布が ある実際の廃裹物最終処分場内のメタン平均濃度 を正確かつ簡便に把握できることを示し，提案し た計測手法が埋立ガスによる作業環境への影響や 埋立廃裹物の安定化の進行状況の把握等に活用可 能であることを明らかにした。

\section{参考文献}

1) 廃裹物学会廃裹物埋立処理処分研究部会：廃裹物最終 処分場廃止基準の調查評価方法, pp. 28-29（2002）

2) 平成 10 年 6 月 16 日号外総理府・㕌生省省令第二号 :
一般廃棄物の最終処分場及び産業廃衰物の最終処分場 に係る技術上の基準を定める命令の一部改正について (1998)

3）井上雄三，田中 勝：都市ごみ埋立処分場における温室 効果ガス $\left(\mathrm{CH}_{4}\right)$ 排出量の推定法とその抑制対策の検 討, 第 14 回全国都市清掃研究発表会講演論文集, pp. $266-268$ (1993)

4) J.W. Park and H.C. Shin: Surface Emission of Landfill Gas from Solid Waste Landfill, Atmospheric Environment, 35, pp. 3445-3451（2001）

5 ）厚生省生活衛生局水道環境部：廃裹物最終処分場にお ける温暖化ガスの処理及び地盤の安定化技術開発調查 平成 4 年度報告書, p. 2 (1993)

6 ) T. Ishigaki, M. Yamada, M. Nagamori, Y. Ono and Y. Inoue: Estimation of Methane Emission from Whole Landfill Site Using Correlation between Flux and Ground Temperature, Environ. Geol., 48, pp. $845-853$ (2005)

7 ）小峯美奈子, 上野広行：都内における大気中メタンの 濃度変動：東京都環境科学研究所年報 2004,pp. 1823 (2004)

8 ）谷川 昇, 武本敏男：廃裹物埋立処分場からのメ夕ン発 生量の推定, 都市清掃, 第 51 巻, 第 224 号, pp. 283286 (1998)

9 ) N. Tanikawa, T. Oikawa, K. Ishii and T. Furuichi: Monitoring of Methane in Ambient Air as an Index of Stabilization at Landfill Sites, AsianPacific Landfill Symposium, pp. 128-131 (2002)

10） JIS B 7991 : 試料非吸引採取方式による排ガス中の二 酸化硫黄自動計測システム（2002）

11) I. Watanabe, M. Yamada, M. Ohsako, Y. Inoue T. Ikeguchi, M. Tanaka, H. Ohba, N. Tanikawa and Y. Matsuzawa: Techniques for Methane Emission from Waste Disposal Sites, Asian-Pacific Landfill Symposium, pp. 428-435 (2000)

12) N. Tanikawa, T. Furuichi and K. Ishii : Monitoring of Methane and Carbon Dioxide in Ambient Air at Landfill Sites, Proceedings Sardinia 2003, Ninth International Waste Management and Landfill Symposium (2003)

13) T. Iseki: A Portable Remote Methane Detector Using an InGaAsP DFB Laser, Environmental Geology, Vol. 46, pp. $1064-1069$ (2004)

14) T. Iseki, H. Tai and K. Kimura: A Portable Remote Methane Sensor Using a Tunable Diode Laser, Meas. Sci. Technol., Vol. 11, pp. 594-602 (2000)

15）井関孝弥：半導体レーザーを用いた遠隔ガス漏洩検知 器, 検查技術, 第 6 巻, 第 12 号, pp. 38-42 (1998)

16）住友スリーエム(侏：スコッチライト反射シートダイヤ モンドグレード（プリズム型）カタログ 


\title{
Applicability of a Monitoring Method for Methane in the Ambient Air at Landfill Sites Using a Portable Open-path Analyzer
}

\author{
Noboru Tanikawa*, Toru Furuichi*, Kazuei Ishii*, Koji Matsuo* and Takaya Iseki** \\ * Laboratory of Sound Material-Cycle Systems Planning, Graduate School of Engineering, \\ Hokkaido University \\ ** Technology Development Dept., Tokyo Gas Co., Ltd. \\ ' Correspondence should be addressed to Noboru Tanikawa: \\ Laboratory of Sound Material-Cycle Systems Planning, Graduate School of Engineering, \\ Hokkaido University \\ (W8, N 13, Kita-ku, Sapporo, 060-8628 Japan)
}

\begin{abstract}
We have proposed a convenient monitoring method for $\mathrm{CH}_{4}$ concentration in ambient air at landfill sites and investigated its reliability and utility. A portable open-path analyzer (POMA), which is sold as a city gas leak tester, was used together with a retroreflector.

A strong correlation was found between the $\mathrm{CH}_{4}$ concentrations measured using the POMA and those indicated using a flame ionization detector hydrocarbon analyzer (FID). The values of $\mathrm{CH}_{4}$ obtained from the POMA are not dependent on the distance between the instrument and the retroreflector and show good repetition of results. The reliability of the proposed monitoring method is similar to that provided by the FID. The proposed method is a convenient and practical means of monitoring the change of average $\mathrm{CH}_{4}$ concentration in ambient landfill site air. Using it, we determined the influence of landfill gas on working conditions, in addition to the degree of landfill stabilization.
\end{abstract}

Key words : methane, open-path analyzer, landfill site, monitoring, landfill gas 